studies on the European Communities (including a section on law); member-state relations; external relations; and European security. Additional chapters cover reference sources, official publications, periodicals and recommended holdings for small and private libraries. The volume is indexed by both subject and author.

\title{
INTERNATIONAL CENTRE FOR SETTLEMENT OF INVESTMENT DISPUTES (ICSID)
}

The centre, created in 1966 by the Convention on the Settlement of Investment Disputes between States and Nationals of Other States, provides parties to international investment arrangements with a forum for settling disputes through conciliation and arbitration procedures. ICSID arbitration clauses are now widely used in international investment agreements. An important international organization, the Centre operates in conjunction with the International Bank for Reconstruction and Development. The Centre publishes annual reports. The Thirteenth annual report, describing activities during the 1978-79 fiscal year, was issued recently. It is available from the Centre headquarters at $1818 \mathrm{H}$ Street, N.W., Washington, D.C. 20433, U.S.A. The Centre compiles also a looseleaf service Investment Laws of the World, published commercially by Oceana Publications Ltd., Dobbs Ferry, N.Y., U.S.A.

\section{INTERNATIONAL MONETARY FUND LAW LIBRARY RECENT ACQUISITIONS LIST}

For useful and timely information about new books and articles on international law, international trade and finance law, and comparative law, the attention of readers is directed to the monthly list of acquisitions issued by the Law Library of the International Monetary Fund, 1818 H Street, N.W., Washington, D.C. 20433. A special attraction of this list is its reference to publications which do not appear, as a rule, in publishers' catalogs and advertisements.

The value of acquisition lists is frequently questioned. It is said that they may have a limited in-house application, but that no great benefit can be derived from them by other libraries. However, this is not always the case. Several libraries (the most notable being the Los Angeles County Law Library and the Northwestern University Law Library) publish very helpful lists because their content is intelligently selected and arranged. The acquisition list of the International Monetary Fund Law Library belongs to this category. Legal researchers will find it useful. 